\title{
Antimicrobial activities of actinomycete isolates from rhizospheric soils in different mangrove forests of Torosiaje, Gorontalo, Indonesia
}

\author{
YULIANA RETNOWATI ${ }^{1,2, \bullet}$, SUKARTI MOELJOPAWIRO ${ }^{3}$, TJUT SUGANDAWATY DJOHAN ${ }^{3 \vee \bullet,}$ \\ ENDANG SUTARININGSIH SOETARTO ${ }^{3, \vee \vee \vee ~}$ \\ ${ }^{1}$ Biology Postgraduate Program, Faculty of Biology, Universitas Gadjah Mada. Jl. Teknika Selatan, Sekip Utara, Sleman 55281, Yogyakarta, Indonesia \\ ${ }^{2}$ Department of Biology, Faculty of Mathematics and Natural Sciences, Universitas Negeri Gorontalo. Jl. Jend. Sudirman No. 1, Kota Gorontalo 96128, \\ Gorontalo, Indonesia. Tel.: +62-435-821125, Fax.: +62-435-821752. "email: yuliana ri@yahoo.com \\ ${ }^{3}$ Faculty of Biology, Universitas Gadjah Mada. Jl. Teknika Selatan, Sekip Utara, Sleman 55281, Yogyakarta, Indonesia \\ Tel.: +62-274-580839; Fax.: +62-274-6492355, "»email: tjutdjohan@ugm.ac.id, "vv annisah-endang@ugm.ac.id
}

Manuscript received: 10 October 2018. Revision accepted: 4 November 2018.

\begin{abstract}
Retnowati Y, Moeljopawiro S, Djohan TjS, Soetarto ES. 2018. Antimicrobial activities of actinomycetes isolates from rhizospheric soil on different mangrove forests of Torosiaje, Gorontalo, Indonesia. Biodiversitas 19: 2196-2203. Mangrove forests are very productive ecosystems that form unique saline environment very rich in organic matter, containing nitrogen and sulfur available for microorganisms. Mangrove forest as an extreme environment is promising to be sources of antibiotic-producing actinomycetes. The objectives of this study were to analyze the antimicrobial activities of metabolites produced by actinomycete isolates from rhizospheric soil of mangrove forest of Torosiaje, Gorontalo, Indonesia, and identify the active compound for novel antibiotics production. Six isolates from a coastal mangrove forest was selected to produce secondary metabolite. The crude extract of-the six selected actinomycete isolates showed antimicrobial activities against pathogenic microbes; the highest antimicrobial activities was indicated by metabolite

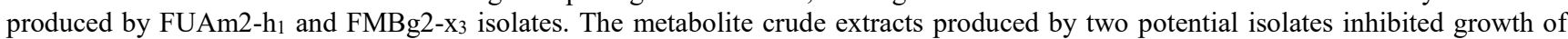
pathogenic microbe on MIC value of 0.0625 to $0.5 \mathrm{mgmL}^{-1}$. Bio-autography assay detected an active compound on $\mathrm{R}_{\mathrm{f}}$ value of 0.94 , especially on extracellular metabolite produced by strain FUAm2- $\mathrm{h}_{1}$. The bioactive compounds were identified by liquid chromatography joined with low-resolution mass spectroscopy (LC/MS) and analysed by MEDINA's database The active compounds composed of 17 substances, and only 3 substances showed a high quantity with molecular weight of 507.37, 344.32 and 563.66 mol G$^{-1}$, respectively. FTIR analyses identified the functional groups in the active compounds consisted of amide, amine, alkuna, alkane, $\mathrm{NO}_{2}$ nitro compound, alcohol, ether, carboxylic acid, ester and C-H aromatic ring. The biosynthesis of antibiotic on FUAm2-h $\mathrm{h}_{1}$ and FMBg2$\mathrm{x}_{3}$ isolates was regulated by double genes, i.e., PKS-II and NRPS genes. The antimicrobial activities of two actinomycete isolates

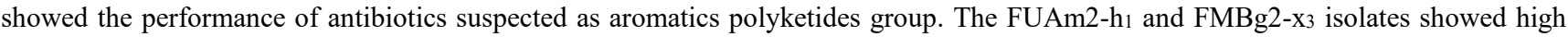
similarity with Streptomyces qinglanensis strain 172205 and Streptomyces sanyensis strain 219820, respectively, in terms of 16S rRNA gene sequences. The potential of those selected actinomycetes from extreme environments of mangrove forest constitute a source of promising actinomycete strains producing biologically active secondary metabolites.
\end{abstract}

Keywords: Actinomycetes, antibiotics, mangrove forest, rhizospheric soil,

\section{INTRODUCTION}

Antimicrobial resistance pathogenic bacterium is not new issue, but the number of resistant organisms is unprecedented (Shetty et al. 2014). Some of pathogenic bacteria are known to be resistance on more than one antibiotics or multidrug resistance, such as Staphylococcus aureus and Escherichia coli (Sharma et al. 2011). Therefore, various efforts have been made to obtain actinomycetes having new type of bioactive compounds with specific characters. Some species of actinomycetes from various sources estimated to have a potential of producing new type of bioactive compounds for antimicrobial agent.

Mangrove forest in Torosiaje, Province of Gorontalo, Indonesia is a unique mangrove ecosystem. There are consist of two types mangrove forest, i.e., overwash and fringe mangrove, including seven kinds of mangrove, i.e., Rhizophora mucronata, Rhizophora apiculata, Bruguiera gymnorrhiza, Ceriops tagal, Avicennia marina, Xylocarpus sp. and Sonneratia alba (Katili et al. 2015). Both types of mangrove showed differences physicochemical characters of sediment soil affecting the population, diversity, and distribution of actinomycetes (Retnowati et al. 2017). Mangrove rhizosphere is a natural habitat for actinomycetes producing a new type of antibiotics (Santhi et al. 2010; Baskaran et al. 2011; Khanna et al. 2011; Naikpatil and Rathod 2011; Ravikumar et al. 2011; Mangamuri et al. 2012, 2014). The specific conditions of the habitats tend to stimulate the actinomycetes to produce the metabolites as response against extreme environments (Basilio et al. 2003).

Mangrove actinomycetes become a major focus in the searching of bioactive compounds from an extreme environment for pharmaceutical agents (Nolan and Cross 1988; Mangamuri et al. 2014). They are an important source of novel antibiotics products (Xu et al. 2014). Therefore, the analyses of antimicrobial activities of metabolite produced by actinomycetes isolated from mangrove rhizosphere on mangrove forest of Torosiaje, 
Gorontalo, and identification of the active compound were required. $\square$

\section{MATERIALS AND METHODS}

\section{Screening of actinomycete isolates for antimicrobial activity}

The 167 actinomycetes isolates collection were preceded to preliminary screening for antibacterial activity by using agar block method (Nedialkowa and Naidenova 2005). In agar block method, firstly the Muller Hinton agar plates were perforated using sterile cork holes $5 \mathrm{~mm}$ in diameters. Then the actinomycetes isolate ware inserted into the hole. The plates were incubated for $96 \mathrm{~h}$ at $30^{\circ} \mathrm{C}$. After the actinomycetes cultures growth well, the antimicrobial activity was screened by pouring the overnight culture of 3 different pathogens bacteria, E. coli, S. aureus, and Bacillus subtilis, at the surrounding of actinomycetes cultures. The plates were incubated at $37^{\circ} \mathrm{C}$ for 18 to $24 \mathrm{~h}$ and the inhibition zone was recorded. The isolates which showed anti-bacterial activities against pathogen bacteria were collected.

\section{Cultivation Experiment and extraction of antibiotic}

The six selected isolates were used as inocula for producing potential new antibiotics through cell cultivation experiments on the ISP 2 broth. The flask was incubated for $48 \mathrm{~h}$ at $30^{\circ} \mathrm{C}$ at $160 \mathrm{rpm}$. The pellet cell was harvested using centrifugation at $4000 \mathrm{rpm}$ for $35 \mathrm{~min}$ (Phongsopitanum et al. 2014). One gram of the pelleted cell was aseptically transferred onto $100 \mathrm{ml}$ of ISP2 broth as a production medium and incubated on rotary shaker (160 rpm) at $30^{\circ} \mathrm{C}$ for 20 days. During cultivation experiment, bacterial growth was monitored based on dry weight of pellet cell observed every two days (Naikpatil and Rathod 2011).

The production of antibiotic was based on shake flask method on ISP2 broth. The cultures of selected actinomycetes isolates were grown in ISP2 broth $(500 \mathrm{~mL})$ on rotary shaker $(160 \mathrm{rpm})$ at $30^{\circ} \mathrm{C}$ for 10 days. The cultures were centrifuged on $4000 \mathrm{rpm}$ for $35 \mathrm{~min}$ at $4^{\circ} \mathrm{C}$ to separate the pelleted cell and culture aliquot (supernatant). The extracellular (supernatant) and intracellular (biomass) antibiotic were extracted using ethyl acetate $(1: 1 \mathrm{v} / \mathrm{v})$ and acetone $(1: 1 \mathrm{v} / \mathrm{v})$ as a solvent, respectively (Mangamuri et al. 2014; Kesavan and Hemlatha 2015). The mixture of supernatant and solvent was shaker vigorously for $1 \mathrm{~h}$ and kept stationary for $15 \mathrm{~min}$ to separate the organic phase from the aqueous phase. The pellet cell was destructed by mortar and added $5 \mathrm{~mL}$ of acetone. The mixture was shaker for overnight and centrifuged on $4000 \mathrm{rpm}$ for $35 \mathrm{~min}$ at $4^{\circ} \mathrm{C}$ to separate the cell debris and acetone phase. The organic phase of extracellular or intracellular antibiotic was evaporated on water-bath at $80^{\circ} \mathrm{C}$. The dried crude extract was collected for antimicrobial assay.

\section{Antimicrobial assay and MIC determination of crude extract antibiotics}

Antimicrobial assay of intracellular and extracellular crude extract against microbial pathogens, such as $E$. coli,
S. aureus, B. subtilis, A. niger, and C. albicans was conducted base on paper diffusion method. Antibiotics ampicillin $\left(25 \mu \mathrm{gmL}^{-1}\right)$ and nystatin $\left(25 \mu \mathrm{gmL}^{-1}\right)$ were used as a positive control and $1 \%$ DMSO as a negative control. The dried crude extract antibiotics were dissolved in $1 \%$ DMSO $\left(1 \mu \mathrm{gmL}^{-1}\right)$. The $24 \mathrm{~h}$ young culture of test microbes were aseptically swabbed on Muller Hinton agar plates by spread plate method. The paper disc was put down on the top of agar plates and loaded by $10 \mu \mathrm{L}$ of crude extract. The plates were incubated at $37^{\circ} \mathrm{C}$ for $24 \mathrm{~h}$; the diameter of zone inhibition was recorded (Gulve and Deshmukh 2012).

The highest antimicrobial activity of crude extract was selected and further MIC level was determined based on broth micro well dilution method using 96-well microtiter plate (Kesavan and Hemalatha 2015). Five mg of crude extract was dissolved in $1 \mathrm{ml} 0.1 \%$ DMSO as the stock solution. The stock solution was used for serial dilution on concentration ranging of $0.5 \mathrm{mgmL}^{-1}$ to $0.002 \mathrm{mgmL}^{-1}$. The microbial pathogen was grown up to final OD 0.7 on $\lambda 600 \mathrm{~nm}$. Different concentration of the crude extract was added into 96-well microtiter plate containing $20 \mu \mathrm{L}$ microbial cultures as test in $200 \mu \mathrm{L}$ of nutrient broth (for bacteria) and potato dextrose broth (for yeast). The culture medium (Nutrient broth and potato dextrose broth) without microbial test was used as negative control. MIC of the active metabolite against the microbial test was determined after $24 \mathrm{~h}$ incubation by spectrophotometrically on $\lambda 590$ $\mathrm{nm}$. Each set of experiment was carried out in three replicates. In the similar way MIC of known antibiotics ampicillin and nystatin were also carried out as a standard for comparison.

\section{TLC of crude extract and Bio-autography assay}

Separation of metabolite crude extract was carried out by thin layer chromatography. Respectively $10 \mu \mathrm{L}$ of crude extract were loaded onto 3 silica gel plates GF254 and eluted by using Chloroform-methanol (2: $1 \mathrm{v} / \mathrm{v})$. After ascending, the plate was taken out and dried. The $\mathrm{R}_{\mathrm{f}}$ value was determined using UV on 254 and $366 \mathrm{~nm}$ (Gulve and Deshmukh 2012). The two other plates were sprayed with ninhydrin and dragendorf for detecting the spot, respectively.

Bio-autography assay was carried out by situated dried TLC plate onto the surface of Muller Hinton agar medium which it has been inoculated by the inoculum of microbial test. The plate was incubated in refrigerator for $20 \mathrm{~min}$ for diffusion. The TLC plate then was removed from the agar plate and incubated overnight at $37^{\circ} \mathrm{C}$. The inhibition zone on the media proved the presence of active antimicrobial compound (Sheety et al. 2014; Attimarad et al. 2012). The spot position showing active compound was determined for further purification.

\section{Purification of active compound}

Purification of active compound was carried out by TLC preparative (Barke et al. 2010). The crude extract was loaded onto silica plate and eluted by chloroform-methanol $(2: 1 \mathrm{v} / \mathrm{v})$. The spot position showing active compound was 
scraped and diluted into ethanol absolute. The suspension then was dried and observed using LCMS and FTIR.

\section{LC-MS analysis of active compound}

The detection quantitatively of active compound was carried out based on separation of active compound by LCMS using Shimadzu single quadrupole LCMS-201 0A mass spectrometer completed by HPLC system. The active compound was separated onto ACQUITY UPLC@, BEH C18 $1.7 \mu \mathrm{m}$ column using gradient solvent, such as A: $0.1 \%$ formic acid in the water and B: $0.1 \%$ formic acid in the acetonitrile. The flow velocity followed by 0.35 $\mathrm{mLmin}^{-1}$ : 0.01-0.5 $\min 15 \% \mathrm{~B}, 0.5-7 \mathrm{~min} 15-95 \% \mathrm{~B}, 7-8 \mathrm{~min}$ $95 \% \mathrm{~B}, 8-8.2 \min 95-15 \% \mathrm{~B}, 8.2-15 \min 15 \% \mathrm{~B}$. The mass spectrum was determined in the positive ion mode with capillary voltage on $3.5 \mathrm{kV}$ (Barke et al. 2010 with minor modification).

\section{FTIR analysis of active compound}

The functional groups in the active compounds were determined by FTIR (Sheety et al. 2014). Infra-red (IR) spectrum of the active compound was investigated in $\mathrm{KBr}$ with Perkin-Elmer-IR-683 spectrophotometer.

\section{DNA extraction and PCR amplification of genes involved in secondary metabolism}

DNA extraction was performed as previously described by Retnowati et al. (2017). PCR amplification of PKSs and NRPS genes were conducted by three sets of primer: K1F (5'-TSAAGTCSAACATCGGBCA-3') and M6R (5'CGCAGGTTSCSGTACCAGTA-3) targeting PKS-I gene; $\mathrm{KS} \alpha\left(5^{\prime}\right.$-TSGCSTGCTTGGAYGCSATC-3') and KS $\beta$ (5'TGGAANCCGCCGAABCCTCT-3') targeting PKS-II gene; A3F (5'-GCSTACSYSATSTACACSTCSGG-3') and A7R (5'-SASGTCVCCSGTSCGGTAS-3') targeting NRPS gene (Lee et al. 2014). PKS-I gene amplification was carried out on $25 \mu \mathrm{L}$ volume consisted of $1 \mu \mathrm{L}$ of genomic DNA as template, $12.5 \mu$ l GoTaq (R) Green Master Mix [buffer reaction, deoxynucleotide triphosphate (dNTPs), Taq DNA polymerase, and $\left.\mathrm{MgCl}_{2}\right], 9.5 \mu \mathrm{L} \mathrm{dH} 2 \mathrm{O}$, and $1 \mu \mathrm{L}$ primers, respectively. The thermal cycling condition for PKS-I gene amplification was: pre-denaturation at $96^{\circ} \mathrm{C}$ for $5 \mathrm{~min}$ : 30 cycles at $95^{\circ} \mathrm{C}$ for $1 \mathrm{~min}, 55^{\circ} \mathrm{C}$ for $1 \mathrm{~min}, 72^{\circ} \mathrm{C}$ for $5 \mathrm{~min}$, and post-extension at $72^{\circ} \mathrm{C}$ for $5 \mathrm{~min}$. The thermal cycling condition for PKS-II gene amplification was: pre-denaturation at pre-denaturation at $96^{\circ} \mathrm{C}$ for 2 min: 30 cycles at $96^{\circ} \mathrm{C}$ for $1 \mathrm{~min}, 56^{\circ} \mathrm{C}$ for $2 \mathrm{~min}, 73^{\circ} \mathrm{C}$ for $1.5 \mathrm{~min}$, and post-extension at $73^{\circ} \mathrm{C}$ for $8.5 \mathrm{~min}$. The thermal cycling condition for NRPS gene amplification was: pre-denaturation at pre-denaturation at $95^{\circ} \mathrm{C}$ for 5 min: 30 cycles at $95^{\circ} \mathrm{C}$ for $30 \mathrm{sec}, 58^{\circ} \mathrm{C}$ for $2 \mathrm{~min}, 72^{\circ} \mathrm{C}$ for $4 \mathrm{~min}$, and post-extension at $72^{\circ} \mathrm{C}$ for $10 \mathrm{~min}$. The amplification reaction was performed using Bio-Rad thermal cycler (MyCycler, Bio-Rad, USA). The size of PCR products were 1,200-1400bp (K1F/M6R), 600bp $(\mathrm{KS} \alpha / \mathrm{KS} \beta)$ and 700-800bp (A3F/A7R). Amplification products were analyzed by electrophoresis in $2 \%$ agarose gels.

\section{Bacterial identification by $16 \mathrm{~S}$ rRNA gene sequence analysis}

Genomic DNA extraction, PCR amplification of $16 \mathrm{~S}$ rRNA gen, sequencing of $16 \mathrm{~S}$ rRNA gene and reconstruction of phylogenetic tree were performed as described in Retnowati et al. (2017).

\section{RESULTS AND DISCUSSION}

The characters of mangrove forest of Torosiaje located at sub-district of Popayato, district of Pohuwato, Gorontalo Province, Indonesia (549.14 Ha) consisted of two types of forest, namely overwash and fringe mangrove. The topography differences of both of forest type influence to the diversity and distribution of actinomycetes on different mangrove type and location (Retnowati et al. 2017).

\section{Metabolites containing in actinomycetes isolates}

According to preliminary screening for antimicrobial activity of actinomycetes, only 77 isolates demonstrated their specific characters, included broad and narrow spectrum (Retnowati et al. 2017). Six selected actinomycetes isolates (strains FUAm2- $\mathrm{h}_{1}, \mathrm{FMBg} 2-\mathrm{x}_{3}$, FMRa1-a, OBg4-e, ORm4-a and FUXy2-d) were capable to produce a high antibiotic concentration shown by large inhibition zones and dry weight of crude extract (Figure 1).
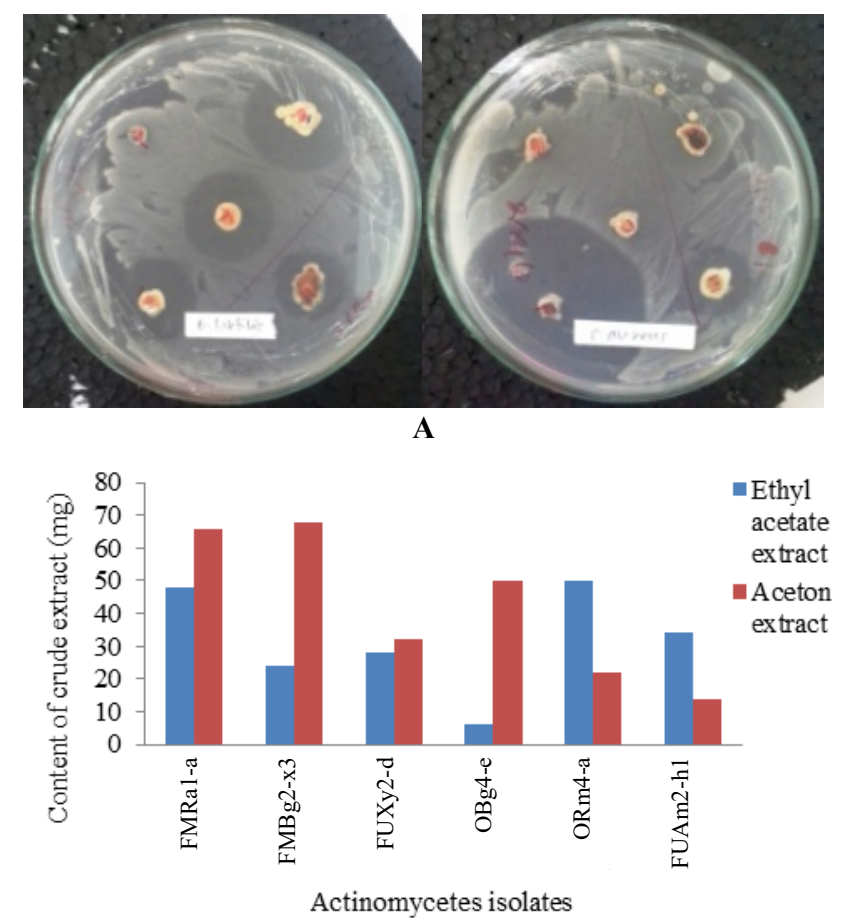

B

Figure 1. The production of antimicrobial compound by actinomycetes isolates. A. detection qualitatively of ability antimicrobial production on actinomycetes isolates after 24-hour incubation; B. The metabolites crude extracts content produced by actinomycetes isolates after ten days cultivation 
The secondary metabolite production quantitatively and qualitatively depended on the strains. The largest inhibition zone indicated the high ability of bioactive compound production by actinomycetes isolates. There were several actinomycetes isolates could not produce antimicrobial compounds shown by no inhibition zone. Strain OBg4-e showed the lowest ability to produce extracellular metabolites, while the ORm4-a, and FMRa1-a were opposite; and the lowest production ability of intracellular metabolite shown by strain FUAm2- $h_{1}$. The secondary metabolite biosynthesis, especially antibiotic is a specific property of microbes which depends on culture conditions (Ripa et al. 2009; Bundale et al. 2015). The production of secondary metabolite is influenced by various environmental factor including nutrient (nitrogen, phosphorous and carbon source), growth rate, feedback control, enzyme inactivation and variable conditions (oxygen supply, temperature, light, pH) (Ozkay 2011; Bundale et al. 2015). As the most significant component in the medium, carbon sources plays a critical role as sources of precursors and energies for the synthesis of biomass building block and secondary metabolite production (Ripa et al. 2009; Ozkay 2011; Bundale et al. 2015).

\section{Antimicrobial activities of metabolite crude extract}

The actinomycetes strains FUAm2- $\mathrm{h}_{1}$ and FMBg2- $\mathrm{x}_{3}$ were the most potential strain as producing antibiotics with the highest antibacterial and antifungal activities (Figure 2). The metabolites crude extracts showed antibacterial activities against $E$. coli, $S$. aureus, B. subtilis. The antibacterial activities were different among crude extract; the highest inhibition of crude extract showed on the growth inhibition of $E$. coli on 6.15 to $14.65 \mathrm{~mm}$ of clear zone diameters. However, several metabolites crude extract did not inhibit the growth of B. subtilis and $S$. aureus. Overall, antibacterial activities of metabolites crude extract tend to be lower than the antibacterial activities of standard antibiotics, such as ampicillin and chloramphenicol on clear zone diameters of 11 to $14 \mathrm{~mm}$ and 25 to $31.7 \mathrm{~mm}$, respectively. The metabolites crude extract showed the highest inhibition on the growth of $A$. niger on the clear zone diameters of 1.5 to $19.7 \mathrm{~mm}$. The data also showed that secondary metabolite produced by several actinomycetes isolates did not inhibit the growth of $C$. albicans. That was indicated that secondary metabolite produced by actinomycetes isolates had specific target to influence the growth of organisms. However, the antifungal activities of metabolites crude extract produced by the six selected actinomycetes isolates tend to be lower than that of antibiotics standard, such as nystatin on clear zone diameters of 15 to $30 \mathrm{~mm}$.

The metabolites produced by mangrove actinomycetes showed the activity as antibacterial, antifungal, antiviral and anticancer (Suthindhiran et al. 2010; Amrita et al. 2012; Ravikumar et al. 2011; Doroghazi and Metcalf 2013; Lee et al. 2014; Shetty et al. 2014; Zotchev 2014). The action of antibiotics is specific on especially targets in microbes through binding of compounds or compoundspecific cellular function interaction. That action requires a series of complex processes started by physical interaction

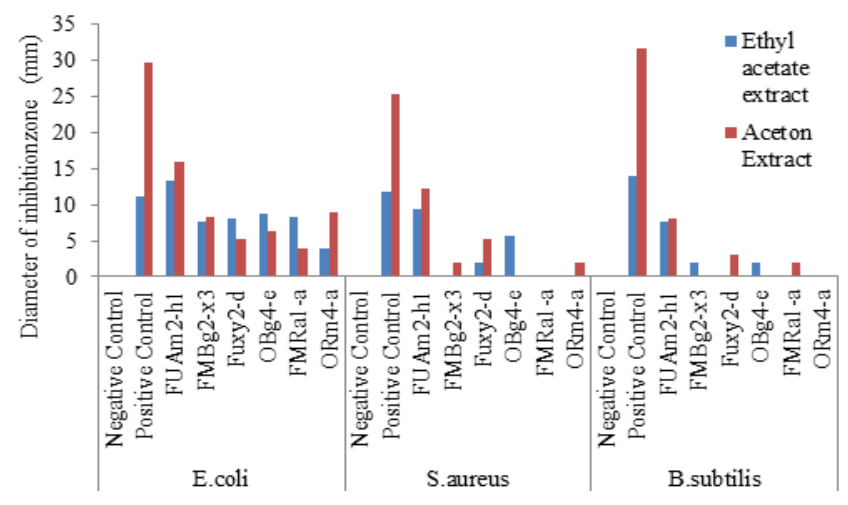

A

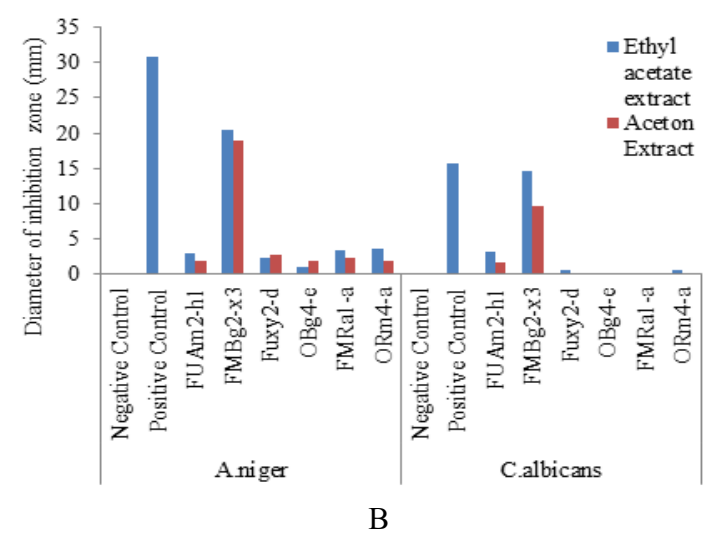

Figure 2. Antimicrobial activities of crude extract metabolites produced by selected actinomycetes isolates. A. Antibacterial activity; B. Antifungal activity

between molecules and specific targets site on microbes. It involves the biochemically, molecularly and structurally changing. Some of important processes in cells affected by antibiotics are DNA replications, RNA biosynthesis, peptidoglycans synthesis and protein synthesis (Maillard 2002; de Lima-Procopio et al. 2012). Antibiotics influence the cells through two kinds of action, cydal action, and static action. The cydal compounds generally have multiple targets sites in microbial cells, and it is able to hardly interact on targets site and overall affects to the destruction of targets sites then induce the biocide effects. The static compounds generally show the weakly physical interaction to lipophilic component in the cell wall of microbes, and affect to the reduction of cytoplasm membrane function and the ruined of proton conductor (Maillard 2002; de Lima-Procopio et al. 2012).

\section{MIC value of metabolites crude extract produced by strain FUAm2-h1 and FMBg2-x3}

The metabolite crude extract produced by two potential actinomycetes isolates showed an inhibition to the growth of microbial pathogen on MIC value of 0.0094 to 0.28 $\mathrm{mg} / \mathrm{mL}$ (Figure 3 ). The metabolites crude extract produced by strain FUAm2- $\mathrm{h}_{1}$ showed the bacteriostatic activities against E. coli, $S$. aureus and $B$. subtilis on the concentration levels of $0.094,0.125$ and $0.28 \mathrm{mgmL}^{-1}$, respectively. However, higher concentration was required to inhibit B. subtilis, especially extracellular crude extract. 
Metabolites crude extract produced by strain $\mathrm{FMBg} 2 \mathrm{x}_{3}$ showed the fungal-static activities to $A$. niger and $C$. albicans on MIC value of 0.125 and $0.25 \mathrm{mgmL}^{-1}$, respectively. The metabolite crude extract effectively inhibited A. niger. However, the MIC values of metabolites crude extract produced by the two selected isolates tended to be lower than MIC value of antibiotic standard, ampicillin, and nystatin. $\square$

\section{Active compounds in metabolite crude extract}

The screening of active compound in metabolite crude extract produced by strain FUAm2- $\mathrm{h}_{1}$ and FMBg2- $\mathrm{x}_{3}$ was carried out based on bio-autography assay. It was started with separation of metabolite using TLC; the result showed that metabolite crude extract produced by strain FUAm2- $\mathrm{h}_{1}$ and FMBg2- $\mathrm{x}_{3}$ separated on three spots (Figure 4).

The bio-autography assay has successfully determined active spot showing inhibition of microbial pathogen growth. The active spot of extracellular metabolite produced by strain FUAm2- $\mathrm{h}_{1}$ on $\mathrm{R}_{\mathrm{f}}$ value of 0.94 inhibited the growth of $S$. aureus (Figure 5). Bio-autography assay is analytical technique in which organic compounds are separated by chromatography and identified by studying their effect on the growth of test microbes. This technique also provides information about the single or multiple compounds that responsible for antibacterial activities. It is very convenient and simple way of testing natural product and pure substances for their effects on pathogenic microbes (Bavya et al. 2011; Shetty et al. 2014).

\section{Characters and identity of active compound}

The characterization and identification of active compound have been conducted based on several ways, such as coloring of spot active on TLC analysis, separation of substance using LC-MS, analysis of functiona groups using FTIR and molecular approach through detection of genes involved in secondary metabolite biosynthesis. The initial detection through coloring of active spot using spotting appearance of ninhydrin and dragendorf on TLC plate exhibited that the active compounds were not member of $\beta$-Lactam and alkaloids groups (Figure 6). Cefixime antibiotic and quinine used as standard substance for $\beta$ lactam and alkaloids, respectively.

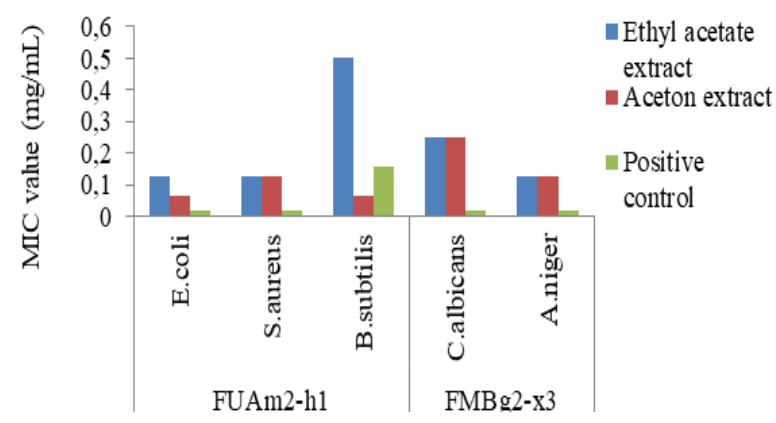

Figure 3. MIC value of metabolites crude extract produced by strain FUAm2-h1 and FMBg2-x3 against pathogenic microbes.

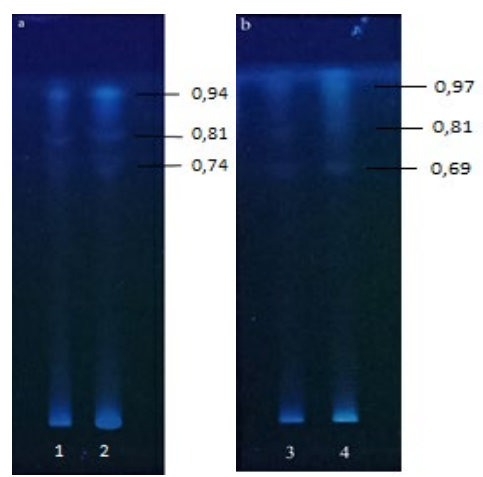

Figure 4. Chromatograms TLC of metabolites crude extract using methanol-chloroform $(2: 1 \mathrm{v} / \mathrm{v})$ as mobile solvent system. a,b metabolite of strain FUAm2-h1 and FMBg2-x3, respectively. 1,3. acetone crude extract; 2,4 , ethyl acetate crude extract

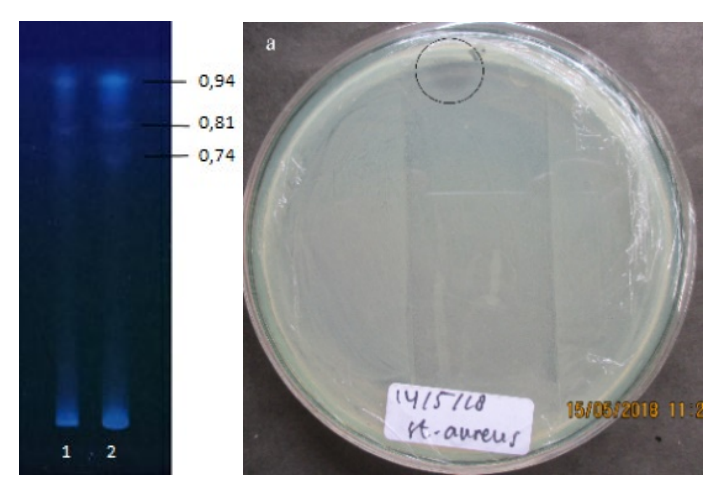

Figure 5. Bio-autography assay of metabolites produced by strain FUAm2- $\mathrm{h}_{1}$

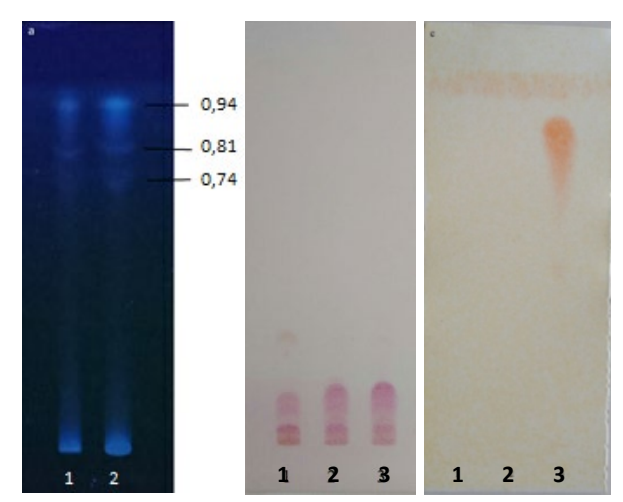

Figure 6. Active spot appearance detected using ninhydrin and dragendorf. a. active spot on $\mathrm{Rf}$ value of 0.94 ; b. ninhydrin coloring; c. dragendorff coloring. Number 1 and 2: intracellular and extracellular metabolite crude extract; 3 . Standard cefixime and quinine respective for $\beta$-lactam and alkaloids.

The liquid chromatography has successfully separated active compound in mixture compounds into 17 peaks on retention time of $20 \mathrm{~min}$ (Figure 7). There were 3 major peaks detected on the retention time of 9.39, 9.93, and $12.84 \mathrm{~min}$; and the molecular weight measured on 507.37 , 344.32 and $563.66 \mathrm{G} \mathrm{mole}^{-1}$, respectively. 
The compound in its IR spectrum exhibits the bands at 3318, 2973, 2927, 2882, 2128, 1925, 1658, 1452, 1419, $1379,1328,1274,1087,1045,880$, dan $803 \mathrm{~cm}^{-1}$ (Figure $8)$; those showed the presence of functional groups consist of N-H (amide, amine, alkuna) on $3300-3500 \mathrm{~cm}^{-1}, \mathrm{C}-\mathrm{H}$ (alkane) on $2850-2970 \mathrm{~cm}^{-1},-\mathrm{CH}_{2}$ - and $\mathrm{C}-\mathrm{H}$ (alkane) on $1340-1470 \mathrm{~cm}^{-1},-\mathrm{CH}_{3}-$, $-\mathrm{C}-\mathrm{N}$ (amine and amide) on 1180 $1360 \mathrm{~cm}^{-1}, \mathrm{NO}_{2}$ nitro compound on $1300-1370 \mathrm{~cm}^{-1}, \mathrm{C}-\mathrm{O}$ (alcohol, ether, carboxylic acid, ester) on 1050-1300 $\mathrm{cm}^{-1}$, alkene on 675-995 $\mathrm{cm}^{-1}$, and C-H aromatic ring on 690-900 $\mathrm{cm}^{-1}$. The functional group of the active compound interacts reversibly with the metabolite receptors in the microorganism target to produce a specific biological response.

The antibiotics production of two potential actinomycetes isolates was regulated by double genes, i.e., PKS-II and NRPS. The genes (PKS-I, PKS-II and NRPS) involved in secondary metabolites biosynthesis; the existence of PKS-II and NRPS genes in chromosomal DNA was appeared in the both of potential isolates of 600 base pairs and 700 base pairs, respectively; however, PKS-I gene was negatively amplificated (Figure 9). PCR amplification of genes involved in secondary metabolites biosynthesis using specific set primer of K1F-M6R, KS $\alpha$ $\mathrm{KS} \beta$, A3F-A7R resulted size of PCR product of 1,200$1400 \mathrm{bp}, 600 \mathrm{bp}$, and 700-800bp, respectively (Lee et al. 2014). The secondary metabolites biosynthesis especially antibiotics are catalyzed by specific enzymes which generally regulated by clusters gene. By the existence of PKS-II and NRPS genes in both chromosomal DNA of actinomycete isolates, showed the antibiotics biosynthesis pathway and the possible types of antibiotics produced (Adegboye and Babalola, 2015). The PKS type I and PKS type II, components of polyketide synthases catalyze synthesys of aliphatic polyketides and aromatic polyketides, respectively. While, the biosynthesis of nonribosomal polypeptide catalyzed by non-ribosomal polypeptide synthase enzymes (Sacido and Genilloud 2004; Ozcan 2017). In conclusion, the active compound produced by strain FUAm2- $\mathrm{h}_{1}$ was predicted as the mixture compounds consisted of aromatic polyketide group and non-ribosomal polypetide.

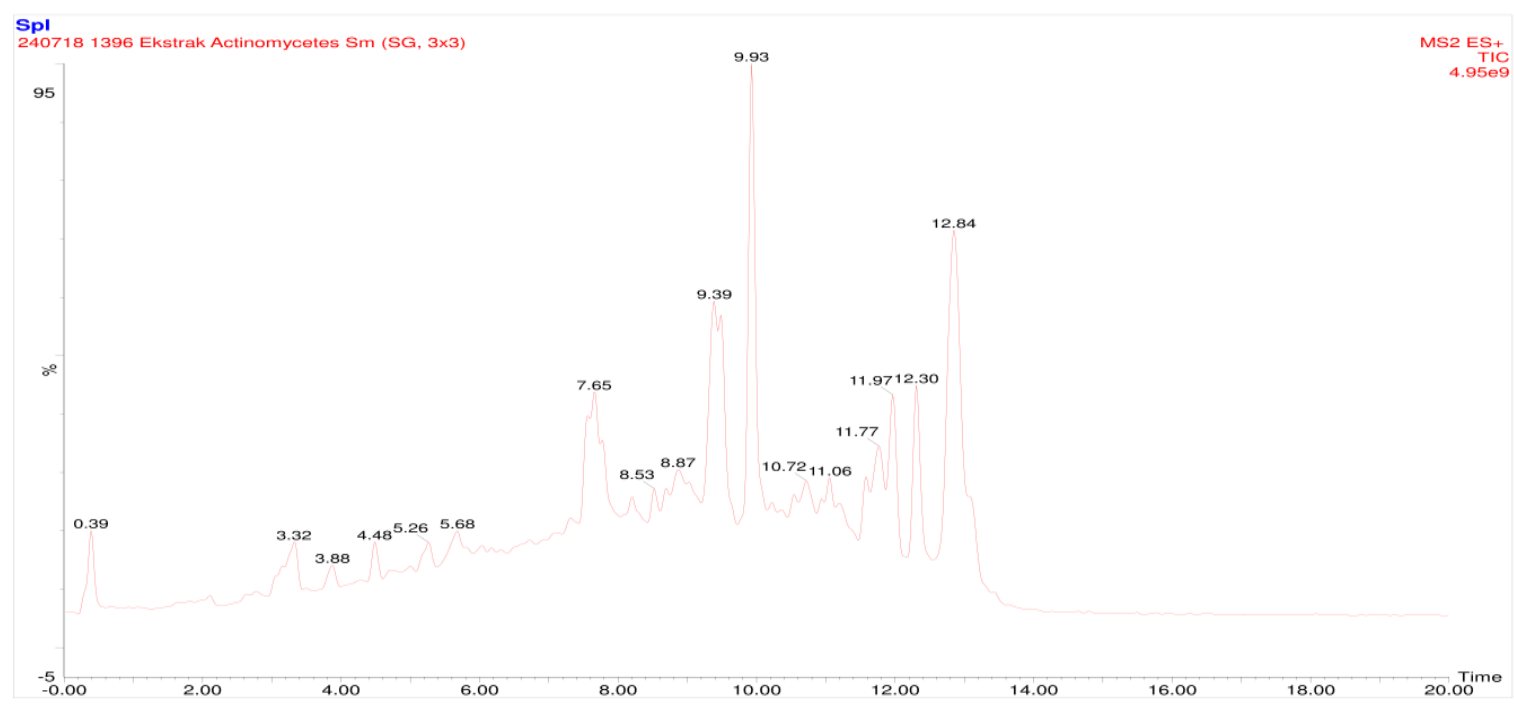

Figure 7. Chromatogram LC of extracelullar active compounds produced by strain FUAm2-h1

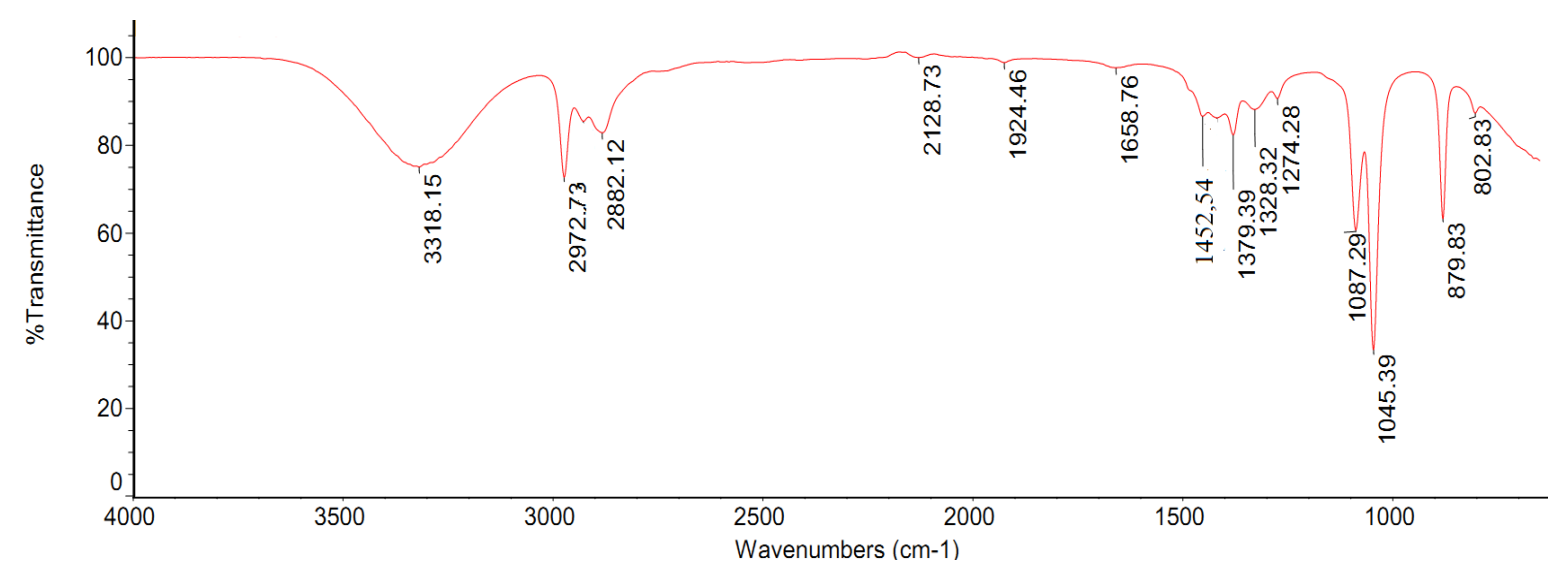

Figure 8. FTIR spectrum of extracelullar active compound produced by strain FUAm2- $\mathrm{h}_{1}$ 

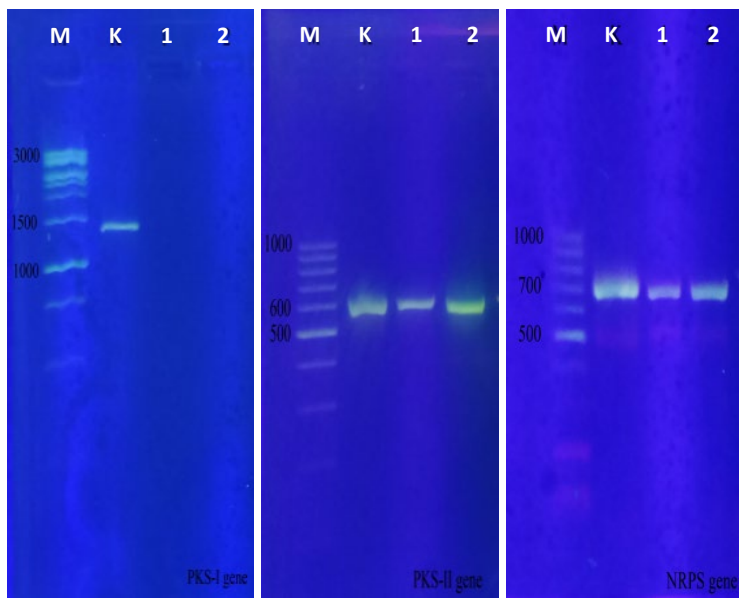

Figure 9. Visualization of PKSs and NRPS genes on 2\% agarose gel electrophoresis. (from left to right: I.M. Marker 100bp plus, 100bp; K. Streptomyces sp; 1. Strain FUAm2-h $\mathrm{h}_{1}$; 2. Strain FMBg2-x3.

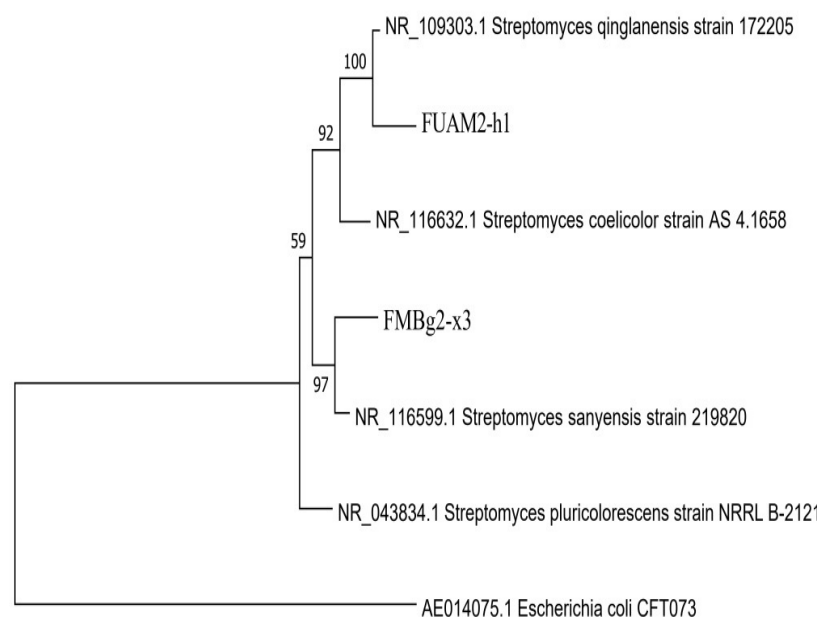

0.020

Figure 10. Neighbor-joining of phylogenetic tree inferred from $16 \mathrm{~S}$ rRNA sequence.

\section{Identity of the potential actinomycetes isolates}

The BLAST analyses of $16 \mathrm{~S}$ rRNA gene sequence data successfully revealed that strain FUAM2- $\mathrm{h}_{1}$ on similarity of $97 \%$ to Streptomyces qinglanensis strain 172205 and strain FMBg2-x3 on $99 \%$ to Streptomyces sanyensis strain 219820. The distinction of phylogenetic position has been observed and also further confirmed for the construction of phylogenetic tree on the Neighbour-joining method (Figure 10). In conclusions, the potential antibiotic-producing isolates designed as Streptomyces qinglanensis strain FUAm2- $\mathrm{h}_{1}$ and Streptomyces sanyensis strain FMBg2- $\mathrm{x}_{3}$.

In conclusion, this study has successfully revealed the antimicrobial activities of secondary metabolites produced by actinomycetes isolates from mangrove rhizosphere on mangrove forest of Torosiaje, Gorontalo, Indonesia. The antimicrobial activities of two actinomycete isolates showed the performance of antibiotics suspected as aromatics polyketides group. The two potential antimicrobial isolates were identified as Streptomyces sp. strain FUAm2- $\mathrm{h}_{1}$ and Streptomyces sp strain FMBg2- $\mathrm{x}_{3}$. The potential of those selected actinomycetes from extreme environments of mangrove forest constitute a source of promising actinomycete strains producing biologically active secondary metabolites.

\section{ACKNOWLEDGEMENTS}

Thankful to Ministry of Research, Technology and Higher Education (Indonesia), Faculty Biology UGM; and Biology Department, State University of Gorontalo (UNG) Indonesia for providing financial support. The authors are grateful to Prof. Langkah Sembiring for his support. We are also thankful to A. Miftah for his help on 16S rRNA gene sequence data analysis.

\section{REFERENCES}

Adegboye MF, and Babalola OO. 2015. Evaluation of biosynthesis antibiotic potential of actinomycete isolates to produces antimicrobial agents. Br Microbiol Res J 7 (5): 243-254.

Amrita K, Nitin J, Devi CS. 2012. Novel bioactive compounds from mangrove-derived actinomycetes. Int Res J Pharm 3 (2): 25-29

Attimarad SL, Ediga GN, Karigar AA, Karadi R, Chandrashekhar N. 2012. Screening, isolation and purification of antibacterial agents from marine actinomycetes. Int Cur Pharm J 1 (2): 394-402.

Barke J, Seipke RF, Gruschow S, Heavens D, Drou N, Bibb MJ, Goss RJM, Yu DW, and Hutchings MI. 2010. A mixed community of actinomycetes produces multiple antibiotics for the fungi farming ant Acromyrmex octospinosus. BMC Biology 8: 109

Basilio A, Gonzales I, Vicente MF, Gorrochategui J, Cabello A, Gonzales A, Genilloud O. 2003. Patterns of antimicrobial activities from soil actinomycetes isolated under different conditions of $\mathrm{pH}$ and salinity. $\mathrm{J}$ App Microbiol 95 (4): 814-823.

Baskaran R, Vijayakumar R, Mohan PM. 2011. Enrichment method for the isolation of bioactive actinomycetes from mangrove sediments of Andaman Islands, India. Malays J Microbiol 7 (1): 26-32

Bavya M, Mohanapriya P, Pazhanimurugun R, Balagurunathan R. 2011. Potential bioactive compound from marine actinomycetes against biofouling bacteria. Indian J Geomarine Sci 40 (4): 578-582

Bundale S, Bedge D, Nashikkar N, Kadam T and Upadhyay A. 2015. Optimatization of culture onditions for production of bioactive metabolites by Streptomyces spp. Isolated from soil. Adv Microbiol 5: 441-451

de Lima-Procopio RE, da Silva IR, Martins MK, de Azevedo JL, de Araujo JM. 2012. Antibiotics produced by Streptomyces. Braz J Infect Dis. 16: 466-471.

Xu DB, Ye WW, Han Y, Deng ZX, Hong K. 2014. Natural products from Mangrove actinomycetes. Mar Drugs 12: 2590-2613.

Doroghazi JR, Metcalf WW. 2013. Comparative genomics of actinomycetes with a focus on natural product biosynthetic genes. Genomics 14: 611 .

Gulve R.M, Deshmukh AM. 2012. Antimicrobial activity of marine actinomycetes. Int Multidiscip Res J 2 (3): 16-22.

Katili AS, Retnowati Y, Djohan TjS. 2015. Vegetation structure of overwash and fringe mangrove forest on Torosiaje, Gorontalo. Unpublished.

Kesavan SS, Hemalatha R. 2015. Isolation and screening of antibioticproducing actinomycetes from garden soil of Sathyabama University, Chennai. Asian J Pharm Clin Res 8 (6): 110-114. 
Khanna M, Solanski R, Lal R. 2011. Selective isolation of rare actinomycetes producing novel antimicrobial compound. Int $\mathbf{J}$ Adv Biotechnol Res 2 (3): 357-375.

Lee LH, Zainal N, Azman AS, Eng SK, Goh BH, Yin WF, Ab Mutalib NS, Chan KG. 2014. Diversity and antimicrobial activities of actinobacteria isolated from tropical mangrove sediments of Malaysia. Sci World J. 2014: 698178. DOI: 10.1155/2014/698178

Maillard JY. 2002. Bacterial target sites for biocide action. J App Microbiol Symp Supp 92: 16S-27S

Mangamuri UK, Muvva V, Poda S, Kamma S. 2012. Isolation, Identification and Molecular Characterization of Rare actinomycetes from Mangrove Ecosystem of Nizampatnam. Malays J Microbiol 8 (2): 83-91.

Mangamuri UK, Vijayalakshmi M, Poda S. 2014. Exploration of Actinobacteria from mangrove ecosystems of Nizampatnam and Coringa for antimicrobial compounds and industrial enzymes. $\mathrm{Br}$ Biotechnol J 4 (2): 173-184.

Naikpatil SV, Rathod JL. 2011. Selective isolation and antimicrobial activity of rare actinomycetes from mangrove sediment of Karwar. J Ecobiotechnol 3 (10): 48-53.

Nedialkova D, Naidenova M. 2005. Screening the antimicrobial activity of actinomycetes strains isolated from Antarctica. J Cul Coll 4 (1): 2935

Nolan RD, Cross T. 1988. Isolation and screening of actinomycetes, p. 132. In: Goodfellow M, Williams ST, Mordarski M. (ed). Actinomycetes in Biotechnology. Academic Press, Inc., San Diego, CA.

Ozcan K. 2017. Screening of PKF/NRPS gene region on marine-derived actinobacteria. J Sci Technol 7 (1): 103-106.

Ozkay M. 2011. Effects some environmental conditions on biomass and antimicrobial metabolite production by Streptomyces sp. KGG32. Intl J Agric Biol 13: 317-324.

Phongsopitanum W, Suwanborirux K, Tanasupawat S. 2014 Identification and antimicrobial activity of Streptomyces strains from Thai mangrove sediment. Thai J Pharm Sci 38 (1): 49-56.
Ravikumar S, Ibaneson SJ, Uthiraselvam M, Priya SR, Ramu A, Banerjee MB. 2011. Diversity of endophytic actinomycetes from Karangkadu mangrove ecosystem and its antibacterial potential against bacterial pathogens. J Pharm Res 4 (1): 294-296.

Retnowati Y, Sembiring L, Moeljopawiro S, Djohan TS, Soetarto ES. 2017. Diversity of antibiotic-producing actinomycetes in mangrove forest of Torosiaje, Gorontalo, Indonesia. Biodiversitas 18 (3): 14531461.

Ripa FA, Nikkon F, Zaman S, Khondkar P. 2009. Optimal conditions for antimicrobial metabolites production from a new Streptomyces sp. RUPA-08PR isolated from Bangladesh soil. Microbiology 37 (3): 211-214.

Sacido AA, Genilloud O. 2004. New PCR primers for the screening of NRPS and PKS-I systems in actinomycetes: detection and distribution of these biosynthetic gene sequences in major taxonomic groups. Mic Ecol 49: 10-24.

Santhi S, Jise AA, Solomon J. 2010. Isolation and characterization of antagonistic actinomycetes from mangrove sediment. Intl J Curr Res 3: $20-23$.

Sharma D, Kaur T, Chadha BS, Manhas RK. 2011. Antimicrobial Activity of actinomycetes Against Multidrug-Resistant Staphylococcus aureus, E. coli, and Various Other Pathogens. Trop J Pharm Res 10 (6): 801808.

Sheety PR, Buddana SK, Tatipamula VB, Naga YVV, Ahmad J. 2014. Production of polypeptide antibiotic from Streptomyces parvulus and its antibacterial activity. Braz J Microbiol 45 (1): 303-312.

Suthindhiran K, Kannabiran K. 2010. Diversity and exploration of bioactive marine actinomycetes in the Bay of Bengal of the Puducherry coast of India. Indian J Microbiol 50 (1): 76-82.

Zotchev SB. 2014. Genomics-based insights into the evolution of secondary metabolite biosynthesis in Actinomycete bacteria. In: Pontarotti P. (ed). Evolutionary Biology: Genome Evolution, Speciation, Coevolution and Origin of Life. Springer, Switzerland. 